\title{
THE TYPE OF CYPELLA HERBERTII SUBSP. BREVICRISTATA RAVENNA (IRIDACEAE: TIGRIDIEAE) ${ }^{1}$
}

\author{
LEONARDO PAZ DEBLE ${ }^{2}$, FABIANO DA SILVA ALVES ${ }^{3}$
}

\begin{abstract}
In the absence of original vouchers deposited in Herbaria of Cypella Herbertii subsp. brevicristata a neotype is proposed, having as base collections performed in the typical region of occurrence, in Artigas Department, Uruguay. Furthermore, description, photos, geographic distribution, conservation data are supplied, as well as its taxonomic relationships are discussed.

Key-words: Artigas, basin of Quaraí river, Neotype, Quaraí.
\end{abstract}

\section{RESUMO}

[O tipo de Cypella Herbertii subp. brevicristata Ravenna (Iridaceae: Tigridieae)].

$\mathrm{Na}$ ausência de coleções originais depositadas em Herbários de Cypella Herbertii subsp. brevicristata um novo tipo é proposto, baseado em coletas realizadas na localidade típica de ocorrência, no departamento de Artigas, Uruguai. Em adição, descrição, fotos, distribuição geográfica e dados de conservação são fornecidas, bem como suas relações taxonômicas são discutidas.

Palavras-Chave: Artigas, bacia do rio Quaraí, Neótipo, Quaraí.

\section{INTRODUCTION}

The genus Cypella Herbert (Iridaceae, Tigridieae) comprises 31 species of bulbous plant with pleated leaves (Deble \& Alves, unp. data), almost totally confined to complex of grasslands ecosystems of Río de La Plata, the most extensive area of grasslands in Southeastern South America (Azpiroz et al., 2012). During the review of the genus Cypella, which is still in progress, it was verified a great number of mistake of identification. Mainly of these problems are due the following factors: (1) few collections represented in herbaria, (2) reduced number of flowers on dry material, (3) bad preservation of specimens, because the structure of perigone is lost during the drying

1 Recebido em 05-01-2017 e aceito para publicação em 26-02-2017.

2 Curso de Ciências da Natureza, Universidade Federal do Pampa, Av. 21 de Abril 80, Dom Pedrito, Rio Grande do Sul, 96450-000, Brazil; e-mail: deble.biol@gmail.com

3 Curso de Ciências Biológicas, Universidade da Região da Campanha, Praça Getúlio Vargas 47, Alegrete, Rio Grande do Sul, 97542-570, Brazil. Núcleo de Estudos Botânicos Balduino Rambo, Universidade Federal de Santa Maria, Santa Maria, Rio Grande do Sul, 97105900, Brazil. process, and (4) absence of types of several names (see Deble \& Alves, 2017).

Ravenna (1965) in his work "Notas sobre Iridaceae 2" published Cypella Herbertii subsp. brevicristata based in material collected by himself in November 1959, in Artigas Department, northern Uruguay. The author differs the subspecies brevicristata mentioning the following diagnosis: "A subspecies typica habito gracillimo, folia peflaccida, floibus minoribus, lutei (haud luteo-aurantiaci vel aurantiaci) filamenta subtota connata, styli ramis brevicristatis, differt", and added the place of occurrence "in septentrione Uruguay in proximus locibus urbi Artigas, in campis inter fruticis".

After Ravenna's publication, the majority of the authors recognized the name $C$. Herbertii subsp. brevicristata as accepted (e.g. Roitman et al., 2008; Hurrel et al., 2009; Barker, 2016). Roitman et al. (2008) give an ample concept to this subspecies, and merged $C$. catharinensis Ravenna (Ravenna, 2005: 1) as a synonym of C. Herbertii subsp. brevicristata. Ravenna (2009) rehabilitated $C$. catharinensis and Deble et al. (2015) and Deble \& Alves (2017) 
recognized $C$. catharinensis as segregated of $C$. Herbertii. However, the status of $C$. Herbertii subsp. brevicristata was not discussed, since $C$. Herbertii was treated in his ample sense.

The absence of type is the principal difficult to correct delimitation of the subsp. brevicristata, in view of some diagnostic features mentioned by Ravenna in the protologue as connate filaments and short crests are found in $C$. Herbertii subsp. Herbertii, which place in doubt the validly of the subspecies brevicristata (Ravenna, 1965; Ravenna, 1981). During the research for the type of $C$. Herbertii subsp. brevicrista in Herbaria was verified the absence of original materials, and probably the collection Ravenna 01 was deposited only in the private herbarium of Ravenna (= Herb. Rav.). The types stored in the "Herb. Rav." were treated as non-existent by Gil (2012), since the material is missing a long time, and this author in an attempt to preserve the usage established by the previous classification, it proposes neotypes to three species of Neomarica Sprague described by Ravenna under Trimezia Salisb. ex Herbert ( $N$. itatiaica (Ravenna) A. Gil, N. latifolia (Ravenna) A. Gil, and N. unca (Ravenna) A. Gil). Most recently, Deble \& Alves (2017), following this same principle recommended neotypes to three species of Cypella with types deposited at "Herb. Rav."(C. discolor Ravenna, C. fucata Ravenna, and C. laeta Ravenna).

Based in facts above mentioned, we decide seek for the place of the type indicated in the protologue of $C$. Herbertii subsp. brevicristata, aiming the accurate taxonomic delimitation, and to propose the nomenclatural type for this taxon. After unsuccessful expeditions in the years of 2011 and 2012, we found in the year of 2015 C. Herbertii subsp. brevicristata exactly as indicated in the protologue, in periphery of the town of Artigas, in grassy associated to shrubs, being possible to propose a neotype to this subspecies. Furthermore, description, photos, geographic distribution, conservation data are supplied, as well as its taxonomic relationships are discussed.

\section{MATERIAL AND METHODS}

To conduct the study, collections from wild populations of Cypella were performed in northeastern Argentina (Corrientes, Entre Ríos, and Misiones Provinces), southern Brazil (Paraná, Rio Grande do Sul, and Santa Catarina States), central and southern Paraguay, and Uruguay, between October 2010 and December 2015. Additionally were evaluated over 4,000 specimens of Cypella (including digital images) deposited in the following herbaria: B, CORD, CTES, FCQ, FLOR, G, HAS, HBR, ICN, K, LP, MVM, MVFA, NY, P, PACA, PY, R, RB, SGO, $\mathrm{S}$, SI, SP, and US (herbaria acronym follows Thiers 2016). The private herbarium of Pierfelice Ravenna is cited under the acronym "Herb. Rav." The morphological description is based on the examined material, and the terminology follows Goldblatt \& Manning (2008), and Beentje (2010).

\section{RESULTS AND DISCUSSIONS}

Cypella Herbertii subsp. brevicristata Ravenna, Not. Bol. Soc. Argent. Botánica 10 (4): 312. 1965. Typus: URUGUAY. Artigas: "Culta in Bonaria ex bulbis collectis in septentrione Uruguay in proximus locibus urbi Artigas, in campis inter fruticis" P.F. Ravenna 01, November 1959 (holotypus: Herb. Rav. not localized). Neotypus (hic designatus): URUGUAY. Artigas: arroyo Pintadito, $30^{\circ} 25^{\prime} 58.91$ 'S and 56 $6^{\circ} 6^{\prime} 45.02$ 'W, L. P. Deble \& F. S. Alves 15996, 6 December 2015 (neotypus $\mathrm{SI}$ ! isoneotypus MVFA!).

Description: Herb 30-70 cm tall, underground stems $4-11 \mathrm{~cm}$ long. Bulb subglobose or ovoid, $15-22 \times 14-16 \mathrm{~mm}$, prolonged in a collar 2-4 cm long; cataphylls brown, broadly ovate-lanceolate, apex acuminate. Basal leaves at anthesis absent or up to 4, blades lanceolate $15-45 \times 0.4-1.5 \mathrm{~cm}$. Cauline leaf elliptic-ensiform, 8.5-20 × 0.8-1.5 
$\mathrm{cm}$, base attenuate. Flowering stems $25-65 \mathrm{~cm}$ long, 3-8 branched in distal half. Spathes $2-6$ per branch, $1.8-3.4 \times 0.3-0.4 \mathrm{~cm}$, herbaceous, pallid-green, bivalved, one-flowered, pedunculate, peduncles $1-3.5 \mathrm{~cm}$ long; outer valve $1.6-1.9 \mathrm{~cm}$ long, the inner $2.2-3.4 \mathrm{~cm}$ long, both obtuse at the top, with membranous and hyaline edges covered with sparse parallel dark brown longitudinal glandular strips; pedicel filiform, $2.5-3.5 \mathrm{~cm}$ long. Flowers $34-40 \mathrm{~mm}$ diameter, yellow, shiny, the concave part with a central brown stripe in the distal part; central concavity 10-12 mm diameter, and 6-8 mm deeper. Tepal whorls notably dissimilar. Outer tepals oblong, 21-29 mm long, yellow, yellow veined, concave at the base for 8-9 mm; blades yellow, with a central brown stripe in the proximal half, $15-20 \times 10-12 \mathrm{~mm}$, slightly patent, apices truncate or rounded, apiculate; claws cuneate, 8-9 mm long, 2.5-3 mm wide at the base, and 8-9.5 mm wide at the apex, dullyellow. Inner tepals geniculate-recurved, 9-10 $\mathrm{mm}$ long, the proximal half patent, slightly inclinate, then curved upward, the distal onethird incurved and strongly reclinate; blades 8 $9 \mathrm{~mm}$ wide, yellow, with a white-cream central depression densely covered with yellow glandular trichomes at the base, surrounded by a lateral high part, with reddish-brown parallel stripes and stains; claws cuneate, 5-6 mm long, 2-2.1 $\mathrm{mm}$ wide at the base, and $4-4.5 \mathrm{~mm}$ wide at the apex, yellow, translucent, with purple parallel stripes. Filaments strap-like 3-3.5 mm long, erect, inclined at top, purplish-cream, base thickened, cream, attached for $1.5-2.8 \mathrm{~mm}$; anthers broadly oblong 6-7 × 3.3-3.8 mm; connective purplish, 3-3.6 $\mathrm{mm}$, thecae darker, pollen dark-grey. Ovary pallid-green, oblong 6$8 \times 1.5-2 \mathrm{~mm}$. Style $8.5-9.5 \mathrm{~mm}$ long. Style branches channeled, almost erect, $2.3-2.8 \mathrm{~mm}$ long, with transverse stigmatic surface of the abaxial crest extending one in the each other crest at the apex, translucent and yellowish, adaxial crests deltate, $0.5-0.8 \mathrm{~mm}$ long, abaxial crest deltate, at apex shortly bifid, $0.5 \mathrm{~mm}$ long. Capsule obovate-oblong, $14-18 \times 3.5-5 \mathrm{~mm}$.
Seeds obconic, $2-2.5 \mathrm{~mm}$, angled, reddishbrown, epidermis faveolate (Figure 1A, B, C, E and F).

Geographic distribution: The populations of $C$. Herbertii subsp. brevicristata occur near to Artigas town, and display few individuals and usually well separated one of the other, extending since Pintadito stream (place of the coordinate mentioned in the neotype) up to the Pintado Grande stream, in the left bank of the Quaraí river. Others two populations were found, one of them, vicinity at mouth of the Catalán Grande stream with the Quaraí River, and other in the Brazilian territory, near to customhouse Brazil/Uruguay. With the additional data obtained during the review of herbaria was possible check that Cypella Herbertii subsp. brevicristata is reported only to basin of Quaraí river, occurring since the medium course of the Quaraí river extending its distribution up to mouth with the Uruguay river (Figure 2).

Habitat: Cypella Herbertii subsp. brevicristata occurs since clearing among the gallery forest, in sites with deep soils and wet, formed from alluvial-colluvial deposits, associated with the main watercourses, extending up to the grasslands with shrubby community and trees, places where the soils are moderate deep, well drained, and some times, with rocks. The last environments are typical on rolling slope with soils developed from volcanic rocks belonging to Serra Geral geological formation.

\section{Additional specimens examined: \\ Cypella Herbertii subsp. brevicristata}

BRAZIL. Rio Grande do Sul: Barra do Quaraí, propriedade do Sr. Angelo Dovigi, em terreno próximo à beira do rio Quaraí, 5 November 2012, L. Eggers, O. Chauveau \& T. Pastori 741 (ICN 180036!); marco da tríplice fronteira, em clareira em meio a floresta de galeria, $30^{\circ} 11^{\prime} 05.69$ "'S and 57 $35^{\circ} 58.16^{\prime \prime} 3$ 

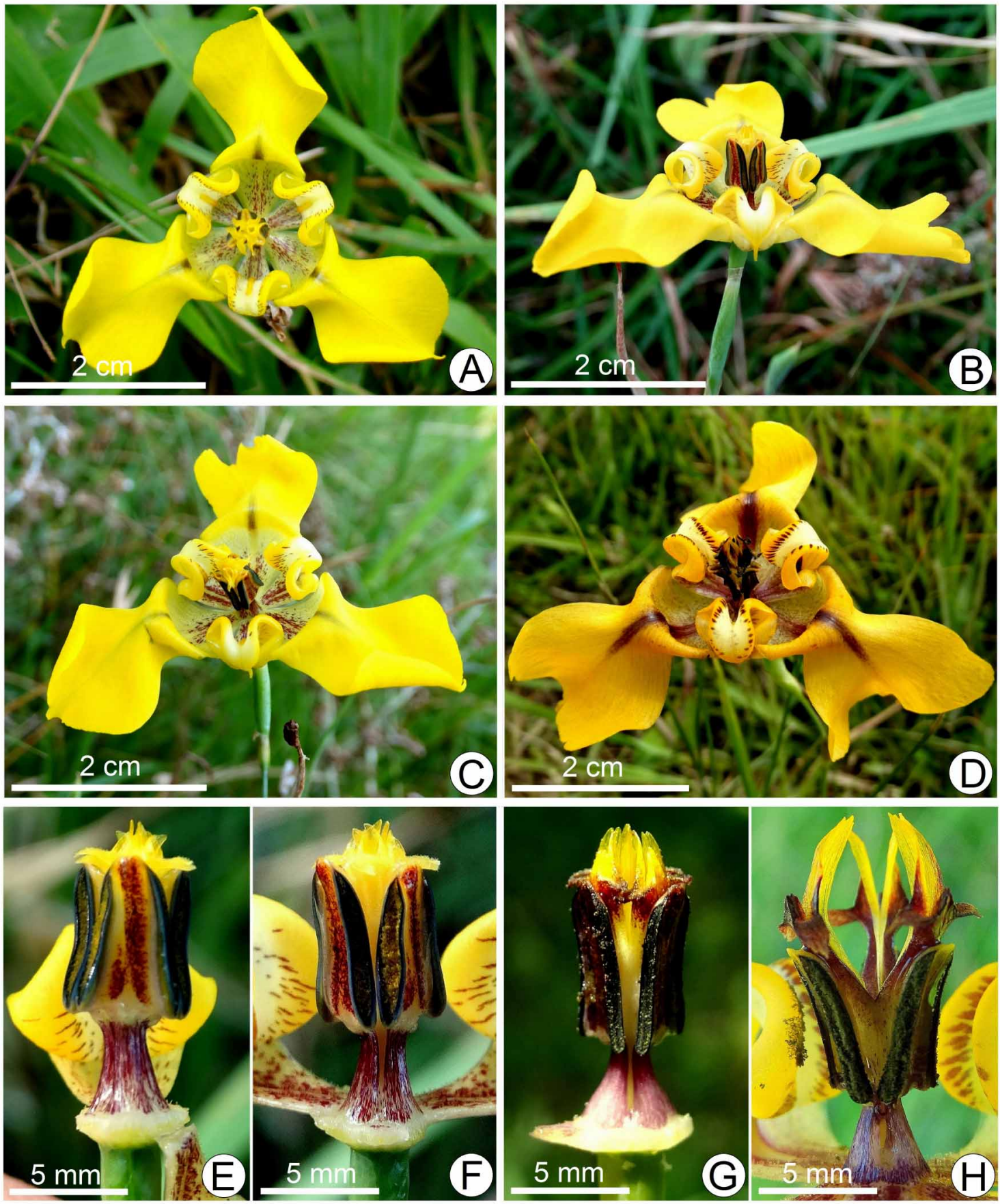

Figure 1. A-C, E,F. Cypella herbertii subsp. brevicristata. A, Flower, upper view. B, Flower, lateral view. C. Flower, inclined view. E, Flower, tepals removed, showing one stamen in frontal view and style. F, Flower, tepals removed, showing two stamens in lateral view and style. D, G,H Cypella herbertii subsp. herbertii. D, Flower, inclined view. G, flower, tepals removed. H, flower, tepals removed (A-C, E, F from Deble \& Alves 15996; D, H from Deble et al. 12337; $\mathrm{G}$ fom Deble et al. 15102). 


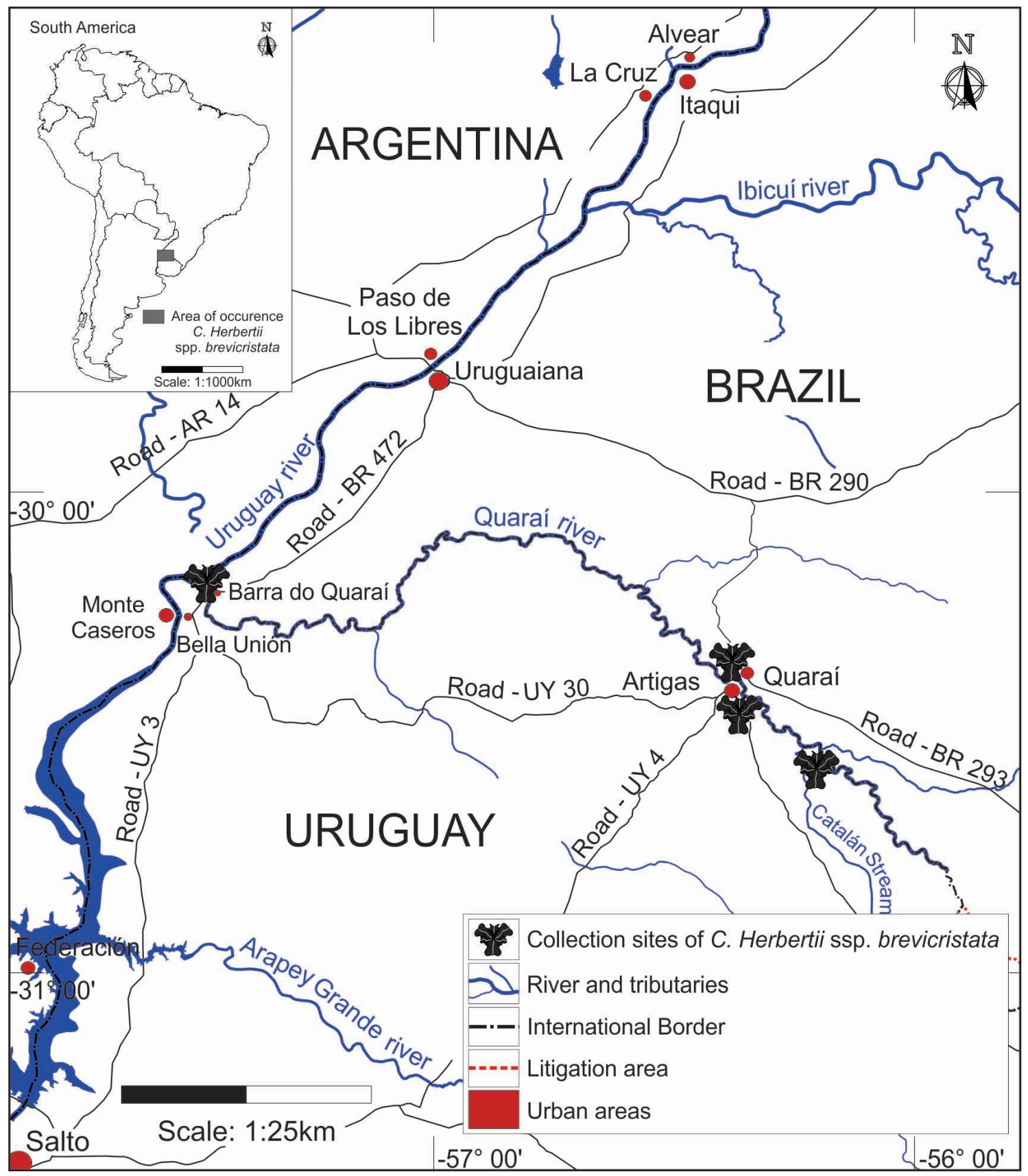

Figure 2. Geographic distribution of Cypella Herbertii subsp. brevicristata. 
December 2011, F. da S. Alves \& J.N.C. Marchiori 842 (SI!). URUGUAY. Artigas, "em campo próximo a planta urbana", 8 November 2014, L. P. Deble et al. 15099 (SI! MVFA!)

Cypella Herbertii subsp. Herbertii

ARGENTINA. Buenos Aires: La Plata, "praderas, flores amarillo-anaranjadas", 18 December 1942, A. L. Cabrera 7554 (SI!). Palermo, December 1907, J. C. Masquijo s.n. (SI 25759!). Entre Ríos: flor amarilla en zonas inundables" 20 December 1957, E. Nicora 6582 (SI!). BRAZIL. Rio Grande do Sul: Rosário do Sul, BR 158, prox. localidade de Guará, 17 January 2011, L. P. Deble et al. 12377 (SI). URUGUAY. Artigas: em campo úmido, flores amarelas, cristas de $1 \mathrm{~mm}, 8$ November 2014, L. P. Deble et al. 15102 (SI! MVFA!) Maldonado: "Pan de azúcar", 19 December 1931, C. Osten 22354 (MVM!); Montevideo: "Cat. de Carrasco", 19 February 1951, D. Legrand 3678 (MVM!); Salto: entre arroyo Espinillar y río Arapey, "area a inundar por la represa Salto Grande", 22-26 November 1977, M. del Puerto 14646 (MVFA!).

Conservation status: Cypella Herbertii subsp. brevicristata occurs in less than 5,000 $\mathrm{km}^{2}$, along the medium course of the Quaraí river extending its occurrence up to mouth with the Uruguay river. The individuals require specific habitat, in clearing areas among the gallery forest and rolling places, where it are associated at tree and shrubs, and probably this subspecies not occurs in full sun. These environments are suffering by the human action, mainly to conversion for agriculture and cattle, and the reduction these ecosystems can to reduce the area of occurrence of Cypella Herbertii subsp. brevicristata, resulting in direct threat to conservation of the taxon. According to the IUCN Red List (IUCN, 2014) the subspecies could be assigned as Endangered (EN, B1, B2a, b(iii)) due to the small extent of occurrence, reduced area of occupancy, specific habitat required, and decline in the quality of habitat.
Phenology and seed production: Specimens with flowers and capsules can be found between October-December. The flowers bloom in the sunrise and wither early afternoon. In cloudy days, the flowers remain opened up to middle afternoon. The flowers are auto-fertile, and the specimens produce a great number of fruits with feasible seeds.

Etymology: Ravenna when designated this subspecies certainly noted the reduced dimensions of the crests of style when compared to Cypella Herbertii subsp. Herbertii.

Taxonomic relationships: Cypella Herbertii subsp. brevicristata resembles $C$. catharinensis and $C$. Herbertii subsp. Herbertii, mainly by stamens, shape of style-branches, and transverse stigmatic surface of the abaxial crest extending one in the each other crest. However, C. Herbertii subsp. brevicristata can be distinguished from $C$. catharinensis by its yellow perigone (vs. orange), and flaccid leaves (vs. rigid). Furthermore, both taxa are isolated geographically by more than $600 \mathrm{~km}$, and grow in different habitat, since $C$. catharinensis occurs on stony grasslands associated to small rivers, at 1,000-1,400 m altitude, whereas $C$. Herbertii subsp. brevicristata occurs on open places near to gallery forest and in the mosaic of grasslands and forest along rolling places. From Cypella Herbertii subsp. Herbertii the subspecies brevicristata can be distinguished by its yellow perigone (vs. golden-yellow or orange), with 34-40 mm diameter (vs. 45-55 $\mathrm{mm}$ ), and style branches often with short crests (Figura 1). The recent described C. parviflora Ravenna ex Deble \& F. S. Alves has similar habitat and general aspect of flowers, however the shape of stamens and style branches are different (see Deble \& Alves, 2017).

\section{CONSIDERATIONS}

The delimitation of Cypella Herbertii subsp. brevicristata evidenced this taxon as segregated of $C$. Herbertii subsp. Herbertii mainly by its 
yellow and smaller flowers, and usually different habitat and revealed that the major part of the material currently recognized as $C$. Herbertii subsp. brevicristata not belong to this taxon, and represent specimens of $C$. Herbertii subsp. Herbertii with short crests of style branches (Figure 1G). With the data obtained was evidenced that the "true" $C$. Herbertii subsp. brevicristata is a rare taxon narrowly endemic along the medium course of the Quaraí river up to its mouth with Uruguay river. Cypella Herbertii subsp. brevicristata occurs in clearing sites among the gallery forest and extending up the grasslands with shrubby community and trees, and probably this subspecies not occurs in full sun. The ecological data mentioned evidenced that subspecies brevicristata require specific habitat, and more demanding of environmental quality than the subspecies Herbertii, the most common and widespread taxon of the genus. With the data obtained, one more taxon of Cypella is added as endemic and threatened in the Northern Campos of the complex ecosystems of Río de La Plata Grasslands, and reinforce the necessity of actions that subsidize the valuation and conservation these environments.

\section{REFERENCES}

AZPIROZ, A. B., ISACCH, J. P., DIAS, R. A., DI GIACOMO, A. S., FONTANA, C. S., PALAREA, C. M. Ecology and conservation of grassland birds in southeastern South America: a review. Journal of Field Ornithology, v. 83, n. 3, p. 217-246.

BARKER, C. World Checklist of Iridaceae. Facilitated by the Royal Botanic Gardens, Kew. Available from: http://apps.kew.org/wcsp/ (accessed 4 October 2016).

BEENTJE, H. The Kew Plant Glossary: an illustrated dictionary of plant terms. Royal Botanic Gardens, Kew, 2010. 160 p.

DEBLE, L.P., ALVES, F. da S., GONZÁLEZ, A., OLIVEIRA-DEBLE, A. S. de. Three new species of Cypella (Iridaceae) from South America, and taxonomic delimitation of $C$. suffusa Ravenna. Phytotaxa, v. 236, n. 2, p.101120, 2015.

http://dx.doi.org/10.11646/phytotaxa.236.2.1

DEBLE, L.P., ALVES, F. da S. Taxonomic novelties for the genus Cypella (Iridaceae): new species, synonymies and nomenclatural types. Kew Bulletin, Kew, v. 72, n.1.

GIL, A. dos S. B. Revisão taxonômica e estudos filogenéticos do gênero Neomarica Sprague. Doctoral thesis, Universidade Estadual de Campinas, Campinas, 2012. 270 p.

GOLDBLATT, P., J. C MANNING. The Iris Family. Natural History and Classification. Portland: Timber Press. 2008. 290 p.

HURREL, J.A., ROITMAN, G., DELUCCHI, G. Iridaceae. In: Hurrel, J.A. Flora Rioplatense, Sistemática, ecologia y etnobotánica de las plantas vasculares rio-platenses. Parte 3 Monocotiledóneas, v. 4, p. 251-326.

IUCN Standards and Petitions Subcommittee. 2014 Guidelines for Using IUCN RedList Categories and Criteria. Version 11. Prepared by the Standards and Petitions Subcommittee. Cambridge U.K. Available from: http:// www.iucnredlist.org/documents/ RedListGuidelines. pdf.

RAVENNA, P. Notas sobre Iridaceae II. Boletin de La Sociedad Argentina de Botanica, v. 10, n. 4, p. 311-322, 1965.

RAVENNA, P. Eight new species and two new subspecies of Cypella (Iridaceae). Wrightia, v. 7, n. 1, p. 13-21, 1981.

RAVENNA, P. New species of South American bulbous Iridaceae. Onira Botanical Leaflets, v. 10, n. 13, p. 39-45, 2005.

RAVENNA, P. A survey in the genus Cypella and its allies (Iridaceae). Onira Botanical Leaflets, v. 12, n. 1, p. 1-11. 2009

ROITMAN, G. G., MAZA, I., CASTILLO J. A. Iridaceae. In: ZULOAGA, F.O., MORRONE, O., BELGRANO, M. J. (eds.) Catálogo de Plantas Vasculares del Cono Sur 1. Monographs in Botany from the Missouri Botanical Garden 107, p. 423-453. 2008.

THIERS, B. Index Herbariorum: A global directory of public herbaria and associated staff. New york Botanical Garden's Virtual Herbarium. Available from: http://sweetgum.nybg.org/ih/ (accessed 15 December 2016). 